\title{
THE UNDISCOVERED COUNTRY: SHAKESPEARE IN PHILIPPINE LITERATURES
}

\author{
Judy Celine Ick \\ University of the Philippines \\ judy_celine.ick@up.edu.ph
}

\begin{abstract}
Far from being a corpus of faithful renderings in local languages, Shakespearean translations in and into Philippine literatures participate in the afterlife of Shakespearean texts where Shakespeare is only one among many points of origin. Taking off from the late nineteenth century, the essay covers Shakespearean texts translated into some major Philippine languages-Tagalog, Kapampangan, Hiligaynon, and Bikolano-over the course of the twentieth century. The essay attempts to locate and describe some key qualities of Shakespearean translations in Philippine literatures, account for the shifting nature of authorship in these local practices of translation, and finally gestures towards probing the question of motivation - why was Shakespearean translation, an activity unsanctioned by colonial governments, pursued anyway?

Read against the backdrop of colonial education and the cosmopolitan nature of Philippine translations of foreign texts, these local versions of Shakespeare display a variety of strategies of cultural accommodation that bespeak a striving towards a reconciliation of the original foreign source with the local culture and the biases and expectations of its readers and audiences. They represent a practice of translation that aspires to reconciliation rather than reproduction, laying bare a process of meaning making in a cross-cultural encounter that actively produces a Filipino Shakespeare rather than merely reproducing the English Shakespeare in a Philippine language.
\end{abstract}

\section{Keywords}

cultural production, Walter Benjamin, postcolonial, Romeo and Juliet, awit, colonial history, author, sawi na pag-ibig

\section{About the Author}

Judy Celine Ick is a professor at the Department of English and Comparative Literature at the University of the Philippines and a part-time faculty member of the Interdisciplinary Studies Department of the Ateneo De Manila University. She is the author of Unsex Me 
Here: Female Power and Shakespearean Tragedy; co-editor (with Mary Racelis) of Bearers of Benevolence: The Thomasites and Public Education in the Philippines (National Book Award for History 2002); and several articles on Shakespeare, performance, and colonial education. She is also an actor and dramaturg noted for her performances of Shakespearean roles with several professional theater companies in the Philippines.

Kritika Kultura 21/22 (2013/2014): -025

(C) Ateneo de Manila University

<http://kritikakultura.ateneo.net> 


\section{Shakespeare's Ghost, Macbeth's Fisherman, and Romeo and Juliet in Bacolor}

Jose Rizal, the Philippines' national hero and indisputable literary genius, certainly knew his Shakespeare. One of the earliest Rizal biographies, Austin Craig's Life, Lineage and Labors of Jose Rizal features a photograph of books from Rizal's personal library that prominently displayed a volume of Shakespeare's works (99). ${ }^{1}$ The presence of Shakespeare in Rizal's library is rather unremarkable as it is indeed unimaginable that a man of Rizal's education and exposure would have been unfamiliar with the Bard even as more continental writers like Alexander Dumas, Eugene Sue, and Hans Christian Andersen were clearly his greater literary influences. Nonetheless, Shakespeare does find his way into Rizal's literary corpus $\neg-$ albeit obliquely. The epigraph to the Noli Me Tangere, a fragment from a poem of Frederich Schiller entitled "Shakespeare's Ghost," for instance, is a fine example of the "almost presence" of Shakespeare in Rizal. Appearing only in the title, as a figure merely addressed and having nothing to do with the poem itself, Shakespeare exists primarily as an absence bemoaned, there only because he is not there. In the same novel, Rizal makes a deliberate mistaken reference to a Shakespearean text; again, Shakespeare-but not quite. In describing the melancholia that ultimately causes the demise of Maria Clara's mother and Capitan Tiago's wife, Doña Pia Alba who is overcome by grief after her "encounter" with the devious Padre Damaso, Rizal likens her to "the fisherman alluded to by Shakespeare in Macbeth, who stopped singing when he found a treasure, she lost her joy became sad and was not seen to smile again" (Noli 39). In this passage, Rizal makes a seemingly direct reference to Shakespeare but only in the manner of a joke-there is no fisherman in Macbeth at all; Macbeth's fisherman is only as real as Capitan Tiago's paternity of Maria Clara. Once again, in Rizal, Shakespeare suggested is Shakespeare denied, a present absence or an absent presence at the same time. In both these instances Rizal's engagement with Shakespeare, via ghost and doubly-fictional fisherman, can be described as spectral, more in the nature of an effect, a resonance, an afterlife.

If one were to search for a more tangible encounter between Rizal and Shakespeare, one would have to turn to his diaries. The 26 April 1884 entry from Madrid tells of one significant encounter: "Tonight I saw Rossi play Hamlet. I spent a very pleasant time seeing how masterly Shakespeare was interpreted." Obviously moved by the performance, his diary entry two days later records the expense of "3.10 pesetas" for "Theater, Hamlet," possibly hinting at a second viewing. That Rizal would have felt an affinity for this specific Shakespearean play eerily presages Miguel de Unamono's famous characterization of him as the "Tagalog Hamlet" (Feria and Daroy). And yet, despite the apparent impact of Shakespeare on Rizal, the Hamlet he felt so compelled by is hardly the Hamlet one would typically expect. This Hamlet was Ernesto Rossi, an acclaimed Italian actor who toured Europe and America in the late nineteenth century, playing Shakespeare in Italian (Carlson). 
Hamlet, an English play set in Denmark in Italian by an Italian actor in a Spanish city is a multiply translated Hamlet. ${ }^{2}$ Even where one expects to find a direct encounter between Rizal and Shakespeare one finds instead Rizal in the face of a Hamlet that is, again, in the nature of an effect, a resonance, an afterlife.

At around the same time Rizal was a student in Madrid but half a world away, a local and only slightly less illustrious literary career is inaugurated. Juan Crisostomo Soto, a future pillar of Kapampangan Literature, writes his first play while a student at the San Juan De Letran. Described as a distracted student by the biographer, E. Arsenio Manuel, Soto nonetheless found his passion, so to speak, while at Letran:

Soto again failed in his first year of stay in San Juan de Letran because he was more absorbed in reading and understanding plays in Spanish than in preparing his lessons. He came across Shakespeare's plays and one of them engrossed him especially; so he started making an adaptation of Romeo and Juliet from the Spanish version into Pampango; this he entitled Ing Pamaquiasaua ning Mete (literally, "The Marriage of the Dead"). (421)

While the text of this play, like many of Soto's early work, is presumably lost to us, it is nonetheless cited by Soto scholars (such as Aguas and Manuel) as his first play and is perhaps best remembered because of its aftermath. Manuel recounts how Soto hurriedly left school soon after the play was completed, returned to his hometown of Bacolor, found a young woman who had previously acted in the popular Kapampangan comedia, Gonzalo de Cordova, and trained her to play Juliet to his Romeo. The play was a flop but in a strange way of life imitating art, or more precisely, of a translation exceeding its text, Soto fell in love with his Juliet, much to the chagrin of both their families. As with Shakespeare's tragedy, this union was not to be and Soto went on to marry a woman of his family's choosing.

Schiller's Shakespearean ghost that haunts Rizal's novel, Macbeth's nonexistent fisherman it invokes, and Soto's scandalous, inversely-mimetic affair illustrate in various degrees the trajectories of the early history of Shakespearean translation in late nineteenth century Philippine literature. Like Rizal's Hamlet and the other spectral presences of Shakespeare in Rizal's texts, the translation of Shakespeare into Philippine literatures partakes of an in-betweeness, of being not quite Shakespeare but being Shakespeare at the same time. Like Soto's uncanny enactment of the vague outlines of his translated text, Shakespeare in Philippine literatures produces the same vague feeling of simultaneous connection and nonconnection, an oblique resonance rather than direct engagement. Far from being a corpus of faithful renderings in local languages, Shakespearean translations in and into Philippine literatures participate in the afterlife of Shakespearean texts where Shakespeare is only one among many points of origin. In a sense, translations of Shakespearean texts in Philippine literatures exemplify the work of translation itself as defined by Walter Benjamin. They lay bare what Benjamin has described as the 
translator's task that "consists in finding that intended effect [Intention] upon the language into which he is translating which produces in it the echo of the original, " an echo that is "able to give, in its own language, the reverberation of the work in the alien one" (i19-20).

What follows is a necessarily incomplete, because initial, ranging through these Shakespearean echoes that reverberate through sections of Philippine literatures, a preliminary charting of an undiscovered country. Neither an exhaustive survey nor chronological history of translation, this essay resembles an early traveler's talemarked by thwarted expectations and nebulous first impressions that constitute a voyage of discovery. It attempts to locate and describe some key qualities of Shakespearean translations in Philippine literatures, account for the shifting nature of authorship in these local practices of translation, and finally gestures towards probing the question of motivation-why was Shakespearean translation, an activity unsanctioned by colonial governments, pursued anyway? It begins with these late nineteenth century traces because earlier records of translation history contain only heavily religious and didactic works with little room for the literary, let alone the English writer Shakespeare (Antonio). Even in Spain, the source of most translated texts prior to the nineteenth century in the Philippines, Shakespeare did not gain popularity and only began to get significantly translated and performed in Spanish in the nineteenth century, undoubtedly owing to the richness of its own secular dramatic traditions that feature a siglo de oro that rivals (if not surpasses) the English Renaissance (Fitzgerald). The increasing cosmopolitanism of Philippine culture, and indeed of most of the world, from the late nineteenth century leads to the apparent introduction of Shakespeare on Philippine shores. Expectedly, the number of translations increase in the twentieth century but do so in ways that force us to rethink the dynamics of cultural production and begin not from the assumption of the superiority of the foreign text but arise from a less than monolithic view of colonial culture where Shakespeare served as simply a source text that needed reworking, even "improving" upon, in order to render it palatable to local consumers, audiences and readers. Local translations of Shakespearean texts lay bare a process of meaning-making in a cross-cultural encounter that actively produces a Filipino Shakespeare, best represented by these vernacular versions, rather than merely reproducing the English Shakespeare in a Philippine language. They participate in the afterlife of Shakespeare and stand as exemplifications of what Jacques Derrida in "Living On/Borderlines" describes as "triumphant translation" that results in "neither the life or the death of the text, only or already its living on, its life after life, its life after death" (82).

\section{Veiled by Histories}

Searching for Shakespeare in Philippine literatures is a not too obvious undertaking that requires laboring under the force of powerful historical narratives. 
Easily obscured by the weight of colonial history and dominant narratives of literary tradition, even a rudimentary translation history of Shakespeare in the Philippines nonetheless throws these conventional historical narratives into specific relief in rather unexpected ways.

First, while expectations of colonial history might lead to the automatic assumption that Shakespeare in Philippine culture was a result of American colonial education in English, these early echoes challenge that simple assumption. The early Soto translation of Romeo and Juliet even hints at the possibility that Shakespeare arrived in the Philippines divorced from his original language. Still, conventional wisdom would have it that Shakespeare came to the Philippines as part and parcel of the American colonial education system. This is not untrue as Shakespeare did play a significant role in colonial education. The 1904 Courses of Instruction for the Public Schools of the Philippine Islands states that "the work in the first half of the third year will be devoted largely to the English Drama; the pupils will read Julius Caesar, The Merchant of Venice, and other plays" (15). This directive effectively inaugurates the study of Shakespeare in the Philippines and the list of prescribed plays was further expanded in later years. Other official documents like the Suggested Books for Libraries For Philippine Public Schools, a bulletin released by the US Department of Education in 1912, stipulates the acquisition of a volume of Shakespeare's Complete Works and Charles and Mary Lamb's Tales from Shakespeare for all public school libraries as well as single volume editions of selected plays (Racelis and Ick 331-335). Some of the earliest Shakespearean performances in the Islands were staged by the schools-the first being a performance of As You Like It by students of the Philippine Normal School in 1910 (Jamias 106). Deeply entwined with the aims of training in the English language, there are no records of performances of Shakespearean plays in any of the native languages in Philippine schools in the American colonial period. Instead we have a number of performances, notably at or by institutions like the Ateneo de Manila and Silliman University (then the Silliman Institute), where local reviewers never failed to comment on the "beautiful diction" of the student actors. The drive towards education in English, in which Shakespeare was heartily enlisted, therefore meant that translations into local languages were unnecessary and students were made to read Shakespeare in English in order to learn that language. Colonial history seemingly effectively confined Shakespeare to the classroom or its extended environs and imprisoned the Shakespearean text in a highly regulated school system. ${ }^{3}$

Soto's early translation of Romeo and Juliet confounds the certainty of this line of thinking as it predates the American colonial period. As does another early translation, this time in Tagalog, of the same text. The year 1901 was a year of twin arrivals on Philippine shores. Almost simultaneous with the official establishment of a Bureau of Education by the American colonial government was the appearance in print of an indigenous metrical romance, an awit, bearing the title, Ang Sintang 
Dalisay ni Julieta at Romeo (The Pure Love of Juliet and Romeo). These texts offer proof that the translation of Shakespeare in Philippine literatures was not necessarily an effect of American colonial education. The theatergoing and reading publics, especially in the local languages, were not necessarily and not always the same as the schooled sectors of the population. In fact, the choice of text for translations speaks of an emerging tradition that existed oblivious to the control of the colonial educational system. Romeo and Juliet appears nowhere in the official documents - prescribed curricula, textbooks, study guides, book purchase listsof the American-imposed educational system. Moreover, the play was specifically forbidden from the repertoires of the Catholic schools. At least one historian of the theater of the time cites "ecclesiastical prohibitions" against the staging of Romeo and Juliet (along with Antony and Cleopatra and Othello) (Bernad 82). After all, this tale of forbidden love, teenage suicide, and the defiance of parental authority with the complicity of at least one friar would understandably not have sat very well with the conservative Catholic church. It is most popular nonetheless in the vernacular traditions not only in print but also in performance. An early, if not only, record of a "Shakespearean" performance in a local language during the American colonial period is a Cebuano linambay called Romeo ug Julieta staged in Carcar in 1917. (Mojares 63). The play's popularity rages in the American colonial period and extends to the postcolonial Philippines, even to the present day. In print, local versions of Romeo and Juliet have appeared as an awit twice in Tagalog (Roke; Gedeere), once as a korido in Bikolano (Imperial), as a rawitdawit also in Bikolano (Lorino), as an early Tagalog novel (De Leon) and as a subject of Tagalog poetry (De Jesus). It has also been adapted into and performed as an Ilonggo zarzuela (Magno) and more recently staged in jologs translation (Binator). It is also the first play translated and published as a performance text in Tagalog in the postcolonial years (Borlaza) and appears as one of the plays in the first local English reprint of Shakespearean plays edited by Asuncion David-Maramba in 1974. Remarkably, Romeo and Juliet appears as a play or as a more straightforward translation of the original text only in the postcolonial years; more frequently and especially during the colonial period, local print editions were also adaptations into local vernacular forms outside the purview of colonial institutions.

Second, just as a misdirected focus on colonial educational history obscures Shakespearean translations from sight, the overwhelmingly Spanish influences on Philippine literatures seem to make Shakespeare a less than obvious object of study and field of translation. Although conventional Philippine literary history in all probability correctly focuses on the tremendous influence of Spanish, especially religious, texts on Filipino literary traditions, there is arguably much to be gained from a widening of perspective that includes the specific history of literary translation. Especially for Philippine languages outside of English, the primacy of literary forms derived from the Spanish - the pasyon, vida, awit and korido, sarswela, among others-seem to have little to do with Shakespeare. A closer examination 
of the specific histories of translations in different Philippine languages, however, not only reveals some Shakespearean or Shakespeare-derived texts but more importantly, sheds some light on the nature of translations in general and offers relevant contexts against which to view these translations. Even a cursory survey of a specific Philippine literature can be illustrative and enlightening. Lilia Antonio's impressive (albeit incomplete) bibliography of foreign translations into Tagalog, Apat na Siglo Ng Pagsasalin, shows that by the early twentieth century, Tagalog writers had translated and published an array of texts from places like Russia, France, Italy, Arabia, Japan, Germany, India, and even Peru and Australia. While many texts were by Spanish writers, Filipino writers in the early twentieth century also translated some American writers like Edgar Allan Poe, Henry Wadsworth Longfellow and Ralph Waldo Emerson but more from the likes of Rabindranath Tagore, Dwarakanath Gangopadya, Dante Alighieri, Alexandre Dumas (per et fils), Victor Hugo, Kenjiro Tokutomi, and Emperor Mutsuhito of Japan. An even more targeted annotated list of Tagalog translations, Patricia May Jurilla's Bibliography of Filipino Novels, 1901-20oo, identifies ninety-five Tagalog translations of foreign novels produced throughout the twentieth century. Again, the novels are not limited to Spanish source texts and include titles from Polish and Flemish as well as those from the expected German, Italian, English, and French. Furthermore, not all source texts were novels themselves, as in the case of Pascual de Leon's Bulag ang Pag-Ibig, a version of Shakespeare's Romeo and Juliet, in novel form.

What this brief sampling reveals is an eclectic but highly cosmopolitan selection of translated texts. Some are described as being translated from Spanish translations of the originals but the exact number of texts translated from the original languages or from Spanish translations is difficult to determine. Viewed against this context, Rizal's Hamlet, a performance of the English play by an Italian actor in Italian translation in a Spanish city, is not so odd after all and would fit right into the cosmopolitan nature and diffusions of origins of Shakespearean texts in Philippine literatures. Like Rizal's Italian Hamlet, Shakespeare managed to land on our shores, sometimes via continental sources, and was promptly translated into local literary forms.

\section{Origins and Originals}

G.D. Roke's Ang Sintang Dalisay ni Julieta at Romeo offers us a case in point. At least partially derived from Shakespeare but written in the style of a metrical romance or an awit, the same text, with slight changes in title and authorial attribution, goes through a second printing in 1914, a relative rarity for non-religious texts in Philippine publishing history. The 1914 edition is entitled Julieta at Romeo o Sintahang Dalisay, the awit is now purportedly written by one named Gedeere. In the foreword to the 1901 text, Ang Sintang Dalisay ni Julieta at Romeo, the author explains that the awit, while not original, is specifically made for its presumably 
Tagalog/Filipino audience (di sariling catha't may quinunang ugat, linangcapang acma at cayang saguisag). ${ }^{4}$ These cultural adjustments manifest in several ways. First of all, the text is cleaned up. All the bawdiness disappears-along with the Nurse and Mercutio, arguably the bawdiest characters in Shakespeare's play. In its place, one finds stanza upon stanza of moralizing and editorializing on the action as when the Capulets arrange the marriage of Juliet to Paris:

¡O mga magulang na maling mag-isip

ang anac sa isang hindi sinta't ibig,

¿baquit pipilitin, tunay masasapit

cun di dalamhati, sa pita'y malihis? ${ }^{5}$

Of course, it is rather unfair to compare this awit exclusively to Shakespeare's play as its source is clearly not only Shakespeare. In her analysis of the 1914 edition of Sintahang Dalisay, Dr. Damiana Eugenio concludes that the text "was not derived from any one source. The poet probably collected from all known accounts of the story the details that appealed to him and wove them into his story. At every possible occasion, he inserted long moralizing stanzas which make up approximately half the bulk of the romance" (145). She names and compares this awit to four other sources aside from Shakespeare's: the Italian Mateo Bandello's "Romeo e Giulietta" (itself derived from Luigi Da Porto's novella Historia novellamente ritrovata di due nobili amanti), William Painter's The Palace of Pleasure, and Arthur Brooke's "The Tragicall History of Romeus and Juliet" (both derived from a French re-telling of the tale in Pierre Boaistuau's Histoires Tragiques). Sintang Dalisay seems to be a pastiche of these versions of the Romeo and Juliet legend where the author of the awit picks up the Prince's speech after the opening brawl, the dialogue between Paris and Lord Capulet and even Juliet's age from Shakespeare, the balcony scene and the title from Bandello and Brooke, and the first meeting at the dance from Da Porto. Seen against the history of foreign translation, the text is like that history in that it comes from multiple sources, the range of sources in keeping with the cosmopolitan nature of literary translation in the early 2oth century.

This highly-mediated and multiply-sourced text certainly disturbs some of the usual binaries employed most often by translation theories-the distinctions between source and target languages and the gaps between the local and the foreign. Which is the source language here exactly? How do translation theories begin to explain simultaneous or multiple origins? When translation happens in cosmopolitan settings where multiple sources are available, what then? What happens to the concept of source language when there are source languages? Moreover, this cosmopolitan-ness carries over into the literary form in the target language as well. While decidedly a local form, the awit is strongly imbued with foreign elements representing an imagined Europe that Vicente Rafael has aptly 
described as "phantasmagoric" (107). Describing the comedia, the awit's dramatic equivalent, Rafael explains:

Comedias conjured a phantasmagoric Europe...Populated by characters and scenes foreign to the Philippine colony, comedias nonetheless present such foreignness in a familiar idiom... lifted from their putative origins and grafted onto native bodies and speech. . .Vernacular dramas estranged "Europe" from itself, splintering it from any unitary concept as a distinct place with its own history. (107)

This imagined, deterritorialized Europe was the landscape of all local awits, koridos, and comedias. Roke's Verona, albeit referring to a real European location, likewise claims its stake on this nebulous local/foreign ground by virtue of its affiliation with the literary form. The dissemination of the text's origins through the variety of source languages and texts is matched by its equally mystified-foreign yet local, real yet fantastic-setting.

Despite the variety of sources, however, one can glean an "original" moment in Roke's Sintang Dalisay that completely parallels none of the sources named by Eugenio (Bandello, Brooke Painter, Da Porto, Shakespeare) and the other possible sources as well (Boaistuau, Groto). Significantly, this original moment takes place at the story's climax and at one of its iconic scenes-the deaths of the main characters. In Shakespeare, as in Boaistuau, Groto, Brooke, Painter, and Bandello, Romeo is dead before Juliet reawakens in the tomb. This tragic detail, however, was apparently unacceptable to the local author; it just wasn't right for the lovers to die without the chance for a final goodbye. So, in Sintang Dalisay, as in the Da Porto account, Juliet awakens in time to find Romeo in the tomb but only after he had already drank the poison creating the opportunity for a melodramatic farewell scene where death is held in dramatic abeyance only long enough for our lovers to bid each other their tearful goodbyes. In this case, "long enough" takes all of forty stanzas (not counting all the ruminations on the nature of tragic love that follows the double suicide). Unlike Da Porto, however, where Juliet kills herself by holding her breath, the author of the awit, perhaps more sophisticated than his medieval source, turns to Shakespeare and has Juliet more realistically and more dramatically stab herself to death.

This moment of authorial intervention, of deviations from and combinations of sources produces a unique death scene perhaps most apropos to its presumed Filipino readership. It dramatizes and highlights the moment of the sawi na pagibig. Doomed, tragic, thwarted, forlorn, unfortunate, ill-fated love, the term sawi na pag-ibig has no direct translation into English yet is at the heart of Filipino literary traditions. Most secular indigenous forms-awit, komedya, sarswela-feature some version of this painful but relished experience of love as its central conflict. Even if narratives finally arrive at the preferred happy endings, usually by magical 
conversions and implausible transformations, their energies converge around the expression of the pains of the erstwhile impossible and potentially tragic love. It is love in this sense that pervades the Filipino literary and cultural ethos and supplies the best explanation for the overwhelming popularity of Romeo and Juliet in the Philippines.

Further proof of centrality of the concept of the sawi na pag-ibig is found in Jose Corazon De Jesus's poem, "Julieta at Romeo," based on Pascual de Leon's rendition of Shakespeare's Romeo and Juliet that also appears at the end of the novel (Bulag ang Pag-ibig). It is a short poem in six sections where the first introduces the story and highlights the Montague-Capulet feud and the last speaks of the resolution of that feud as a result of the actions of Romeo and Juliet, providing this otherwise tragic tale with a requisite happy ending. The bulk of the poem focuses on only two key scenes from the play-the second section describes the balcony scene and the next three (or half the entire poem) detail the deaths of both characters in the Capulet tomb. The contours of this poetic retelling reveal much about what the poet (and by extension a Filipino interpreter of the tale) saw as crucial or essential to the story. Clearly, the emphasis on the forbidden love and its tragic consequences is established in the choice of scenes. Everything else in the original story is inconsequential to this poet/poem. Emblematic of the pains of love, the dual suicides of the main characters are drawn in relatively great detail and obviously constitute the poem's center of gravity.

De Leon's novel, Bulag ang Pag-ibig, is a more straightforward rendition of Shakespeare's text (the title page says "hango sa 'Julieta at Romeo' ni Shakespeare" [taken from Shakespeare's Romeo and Juliet]), albeit still with some cultural adjustments. The bawdiness remains excised from the text, even as it retains the characters of the nurse and Mercutio. The rendering of the lovers' first meeting at the Capulet ball translate the words of the Shakespearean sonnet but divide the lines so that the seduction is not mutual. Romeo is clearly the more aggressive party-he speaks all his lines and kisses Juliet before she even speaks. In this text, as with Shakespeare, Juliet awakens at the tomb after Romeo's death. No forty-stanza goodbyes here. While the text may appear to hew more closely to its declared Shakespearean source, any claims to fidelity are undercut by its form. "To a considerable extent," Paul de Man declares, "translation is a prosaization of the original, always[.]" "[T]ranslation is a making prosaic of what appeared to be poetic in the original" because, he explains, "a translation brings out all that is idiomatical, all that is customary, all that is quotidian. . .in the original" (97). And as such it "desacralizes" and "de-canonizes" via its disarticulation of the original text. De Leon's novel is a stark example of de Man's claims. By literally translating Shakespeare's English poetry into Tagalog prose, De Leon renders the Shakespearean text twice-prosaic and thereby creates something of his own, only in a tangential relation to its origins. 
The same shifts in form are repeatedly found in Shakespearean translations in other Philippine languages as well. The earliest example, Soto's Ing Pamaquiasaua ningMete (The Weddingof the Dead), already exhibits this transformation. Like Roke's and de Leon's, Soto's version of Romeo and Juliet exhibits a clear vernacularization of form even if it is written as a drama. In place of the Shakespearean five-act structure, Ing Pamaquiasaua ning Mete is a one-act play in keeping with dominant local theatrical traditions of the time (Cruz 300). Another dramatic version, Salvador Magno's 1932 unpublished Hiligaynon sarswela, Romeo kag Julieta, was written for and performed by his own company, Ilobac, for contemporary audiences primarily in Iloilo and Bacolod. ${ }^{6}$ Adapted into a three-act sarswela form, this version incorporates townspeople of Verona as characters to populate the choral numbers typical of the form. It features not one but two balcony scenes to make room for dramatic duets by the lead characters and includes a number of plaintive arias for Juliet played by Lydia Magno, the writer/director's eldest daughter who was a frequent and beloved star of his sarswelas.

In 1933, the important Hiligaynon Press, La Panayana, published a vida by Ricaredo Ho entitled Ang Komersiante sa Venecia. Based on Shakespeare's The Merchant of Venice, the text is nonetheless transformed into a vida, a vernacular prose form patterned after the lives of the saints that very often featured admirable or exemplary friendships. This version is therefore subtitled "si Antonio kag si Besanio" highlighting the friendship of Antonio and Bassanio despite the obvious difficulties of imagining the violently anti-Semitic Antonio as a saint. Moreover, the shift in focus from the story of Shylock and his bond or Portia's marriage to the "friendship" of Antonio and Bassanio releases the greater potential for a story about a sawi na pag-ibig, for this Shakespearean subplot turns on the willingness to lose one's life for a friend thereby aligning the text closer to the popular theme.

Even later examples of vernacular translation come out of Bicol in the 1960s. Rosalio Imperial Sr, a former mayor of Naga City and an intrepid translator of Western classics into the korido form, reportedly produced Bikolano korido versions of Shakespeare's Hamlet, Merchant of Venice and Othello (Realubit 169). His version of Romeo and Juliet, Maogma Asin Mamundong Agi-Agi Kan Inaguihan na Buhay ni Romeo asin Juliet sa Ciudad Nin Verona (The Blissful and Tragic Lives of Romeo and Juliet in the City of Verona) was published by the Cecilio Press of Naga City in two parts in 1968. The opening of the text is clearly derived from the awit and corrido tradition and commences with the author's apology and an invocation to the Virgin Mary. The text also exhibits the predilection towards didacticism of the form and the author purposely ends each installment with admonitions to parents, young men, and women freely dispensing advice and underscoring lessons to be learned from the story of Romeo and Juliet. The Bikolano literary historian, Lilia Realubit, notes that the text is quite quaint and anachronistic (169). Given its relatively late date of composition, way past the heyday of the form, however, the text is not impervious to the changes of the times. It ends by rather playfully 
warning young men that modern women have changed and they should be wary of them, momentarily eschewing the grave and serious didacticism of the form.
An daraga ngonian ay iba nang gayo
tataong karate tataong magjudo
kaya an soltero na magloko loko
inda cun saan ilobong an payo
Kaya pangaral ko sa kasolterohan
pilion na gayo saindang namotan
dai baelng makanos sa gayon man kulang
bastang an pagmahal garo na pulutan. (17)

Another notable Bikolano poet, Zacarias Lorino, also produced a translation of Romeo and Juliet, "Si Romeo asin Julieta: Gotos na Kasaysayan sa Rawitdawit," (Romeo and Juliet: A Poem Based on the Love Story) in 1969. The poem appeared on a flier advertising an English-language performance of the play at the Lola Theater in Legaspi, from 14-28 July 1969. It may be surmised that the poem helped to bridge the gap between the English production and its local Bikolano audiences by providing a synopsis of the play in a recognizable mode.

All these examples of Shakespearean translations into a Philippine language also exemplify a transformation of the form. None of them are translated as the five-act dramatic playtext of the Shakespearean original. But, perhaps, the original form was less relevant to the local translators. Seen through more materialist lenses, these textual transformations may also be symptomatic of the commodification of Shakespeare that necessitated translation and adaptation into local forms; in marketing terms, Shakespeare required appropriate packaging. The commodification of the Shakespearean text as print and performance in local markets made imperative that tastes and expectations of reading publics and theater audiences were accounted for; hence, the re-shaping. This would imply then that popular taste and market forces were in some measure instrumental in the translation of Shakespeare into local languages and forms, in turn suggesting that colonial education was not the only or even the major force that determined the shape that Shakespeare took in the Philippines. Because vernacular translations operated outside any colonial agenda and was primarily driven by economic concerns-selling books and theater tickets-its primary loyalty was not to the Shakespearean source but to audiences (for Magno and Soto) and reading publics (for Roke, De Leon, Ho, Imperial, and Lorino).

Beyond the exigencies of form, however, the local texts also display a variety of strategies of cultural accommodation that bespeak a striving towards a reconciliation of the original foreign source with the local culture and the biases and expectations of its audiences. Translation that aspires to reconciliation rather than reproduction, 
in effect, obeys Benjamin's requirement for "the language of a translation" to "let itself go, so that it gives voice to the intentio of the original not as reproduction but as harmony, as a supplement to the language in which it expresses itself, as its own kind of intentio" (21). Despite its foreign Shakespearean origins, these local translations stand as local originals that resonate the Shakespearean texts rather than repeat them. They truly participate in the "afterlife" of the Shakespearean texts that by Benjamin's definition demands the transformation of the original: "for in its afterlife-which could not be called that if it were not a transformation and a renewal of something living-the original undergoes a change" (17).

\section{What's in a name?}

These earlier vernacular translations certainly exhibited a brash independence from their Shakespearean origins, however, the record of translations from postcolonial Manila tells a more intricate story. Also in the 196os, while Rosalio Imperial was composing his quaint Shakespearean koridos in Bikol, a different kind of Shakespearean translation in Tagalog was taking shape in Manila. Unsurprisingly, this course of development was initiated, at least in part, by educational institutions and their affiliates. While no longer directly "colonial," they had certainly evolved from colonialism and its effects. In 1967, the Philippine Women's University and its allied organization, the Bayanihan Folk Arts Association Bayanihan Theater Wing launched a Shakespearean translation contest. One of the judges of the competition, Jose Villa Panganiban, had also previously published a Tagalog translation of Julius Caesar, Julio Cesar ni William Shakespeare, in 1964 in celebration of the quadricentennial of Shakespeare's birth. Most of the entries and winners of the PWU competition were translations of Romeo and Juliet. No first prize was awarded, as explained by the account of the contest in the school publication, The University, because "such is the Bard's magnificence that he cannot be contained in what could infallibly be a definitive, flawless, exact translation" (22). One can glean the exalted status assigned by the institution to Shakespeare in glaring contrast to the status of Shakespeare in the local vernacular versions. The second prize was awarded to Diego Quisao for a translation of Romeo and Juliet. The third prize was split between Bulaklak at Paru-Paru (literally, Flower and Butterfly, a translation of $A$ Midsummer Night's Dream) by Anacieta Encarnacion and Rutica Carpio and Gregorio Borlaza's translation of Romeo and Juliet. The fourth prize also went to another Romeo and Juliet translation by Jose Domingo.

Borlaza's translation, Romeo at Julieta ni William Shakespeare was published by the Philippine Normal University the following year. A second phase of the same competition was launched in 1970 and one of the two winners, a translation of $A s$ You Like It (Sa Kagustuhan Mo) by Pablo Cuasay, was later published by National Bookstore in 1975. The published Tagalog translations from the PWU competition all take on the five-act Shakespearean structure and prominently feature Shakespeare's 
name as part of the title, a practice unknown in other local translations where the translator was clearly identified as author and links to Shakespeare were nowhere in the titles of their works. ${ }^{8}$

Clearly, something else was going on here. While earlier translations were almost non-committal to their Shakespearean origins, these later Tagalog translations were insistent on them. Again, in marketing terms, it would seem that the Shakespearean brand was beginning to take shape and gain ground in Manila in the postcolonial years. More recent published translations in Tagalog in the late twentieth and early twenty-first centuries would seem to bear this out. William Shakespeare's name appears above the title of Ang Trahedya ni Hamlet Prinsipe ng Dinamarka, Rolando Tinio's translation published by the University of the Philippines Press in 1991. It also appears above the title, Julio Cesar, in Bienvenido Lumbera's 2007 translation for the Entablado Klasiko series of Ateneo de Manila University Press. William Shakespeare's name appears on the cover as well of Anvil Publishing's recent 2012 releases of Rolando Tinio's translations of Macbeth (Makbet) and Twelfth Night (Ikalabindalawang Gabi). It would appear that in these later translations of the plays, Shakespeare claims his status as author and reverses the dynamics of authorship at the beginning of the translation history in the twentieth century. Furthermore, it should also not escape notice that more recent translations deemed worthy of publication have come from National Artists, perhaps suggesting the status required to even dare approach and translate the Shakespearean text. Another important change signaled by later translations is the variety of Shakespearean texts subject to translation and publication. No longer almost always confined to the doomed lovers, the list of translated Shakespearean texts expands to include the heretofore untranslated, indicating the increasing importance of Shakespeare as an author rather than as a writer of stories that appealed to local sensibilities.

These later Tagalog translations caution against any facile interpretations of postcolonial paradigms that designate the colonial period as periods of mimicry and veneration of the markers of colonial culture and assigns to the postcolonial the resistance and writing back. The late appearance of Shakespeare's name reverses the expectations set by a crude, temporal understanding of postcolonial theory. It seems rather odd that during the years of actual colonization, translations were more unfettered than they appear to be in the postcolonial age. But it may very well be that the postcolonial Shakespearean translations bespeak a more culturally-aware reading public and a university-based or affiliated intelligentsia that recognized such an audience and produced appropriately attributed texts. Moreover, the task of naming Shakespeare as source can be arguably seen as an assignation that sets what is local (translation) as apart from its "other" (Shakespeare) that at the same time absorbs the prestige of Shakespeare's name into the local language, making, in effect, what is foreign into one's own. ${ }^{9}$ 


\section{In the Name of Shakespeare, In the Name of Love}

Nonetheless, the rough outlines of the translation history of Shakespeare in the Philippines through the twentieth century suggest a change in the nature of translation and the understanding of authorship in relation to it. It raises several questions about the genealogy of authorship and the shifting status of Shakespeare within Philippine culture that remain largely unanswered-if even asked. When did Shakespeare, the author, become Shakespeare, the authority and authorizing agent, in and for Philippine literatures? Or more precisely, when did the name Shakespeare begin to matter? What were the consequences of this shift on the status of the translation as text? And on the translator as the text's creator? The late appearance of Shakespeare's, or for that matter, any name attached to the translated texts, seems to insinuate a different set of motivations for the early and later translations. Clearly, more contemporary translations champion Shakespeare's name, carrying it like a brand or a badge of honor and subsume the translators' name to it. Earlier in the history of translation, however, this was not the case. What authorized the text if not the name of the author? What was it they were translating if not Shakespeare?

Looking to what these early texts themselves declare about the complex nature of authorship and translation provide clues about where answers might lie. As was the common practice among writers of awits and corridos (Eugenio xxi), the author of Sintang Dalisay uses the pseudonym G.D. Roke, later changed to Gedeere in the second edition of the text. Given the range of sources employed in writing this version of the story, one marvels at who this might be. More importantly, the pseudonymous author, like the foreign text itself, identifies himself in the awit's dedicatory foreword as a stranger to the land. At the same time, a few stanzas later, the author identifies the Philippines as "mahal cong bayan" (my beloved country). Both local and foreign, the author positions himself much like a translated text, occupying the tenuous ground between the foreign and the local. Never wholly one or the other, the ambiguity of translated ground makes it potentially dangerous as it represents a littoral space, neither here nor there, where the ground always threatens to give beneath one's feet. At the same time, the lack of firm grounding also implies a transcendence of sorts, a voice from nowhere yet everywhere at the same time. Disembodied and displaced, the authorial voice of this text, and by extension of all translated texts as they too simultaneously partake of the local and the foreign, occupies a potentially powerful space, a space outside of history.

Furthermore, when one reads the extended footnote supplied by the text on the history of Verona, one recognizes that what is highlighted in this long history is its history of colonization by foreign invading powers. ${ }^{10}$ There are hints as well that we are meant to find a correlation between Verona and the Philippines, the foreign source and the native text. In the foreword, the author describes the Philippines as a place threatened by destruction, much like Verona itself: 
Dinala ng palad na di cayat asam

sa natitiualag na Bayanbayanan,

dacong Habagatan ng Sangcapuluan,

at sa di calipi punong pamumuhay, ${ }^{11}$

In the afterword, the poet sings praises to Verona being the staging ground for this story of true love and tantalizingly refers to its colonial history in terms of translation. Verona is likened to a much fought-over gem that has changed hands many times. Curiously, the word employed to describe the changing of hands, salin, is also a word that can mean "translation":

Naguing para ca mang mut-yang punong ning-ning pinag-agauanan at nasalin salin sa iba at ibang liping nagsisupil, ngunit ang sintahang tunay sa iyo'y supling. ${ }^{12}$

What saves Verona, a land constantly threatened by invasion and internal strife, from its fate of certain destruction is true love ("sintahang tunay"). The author certainly saw the writing of this awit, this tale of transcendent love, as a way out of his personal depression as he explains in the foreword. True love, sintahang tunay, is also figured as a remedy for the ills of the Veronese state threatening to implode in the wake of the feud but united in the end as a consequence of the tragic love of Romeo and Juliet. Was the author insinuating the same for the Philippines? ${ }^{13}$

Perhaps this question is answered somehow by the curious Afterword to Pascual De Leon's, Bulag Ang Pag-ibig. Written by another famous novelist, Dr. Juan Rivera Lazaro, and appended to the text, the essay takes up the cudgels for translating foreign texts and espouses a strident, even defensive, rationalization for translating foreign texts by appealing to universal human nature, the timelessness of some texts, and the democratizing impulse of translation.

Ang isipan ng tao ay pangkatauhan. Ipinamamana ang magagandang halimbawa, hindi sa kanyang bansa lamang, kundi para sa buong daigdigan.

May mga pangyayaring hindi namamatay at may mga kathang tumanda man ay para ding bago...

Ang balitang manunulat na si Shakespeare ... ay hindi kailangang maunawa ng mga sahon lamang kundi ng lahat. $(143)^{14}$

Indeed, apart from the value of translation, Lazaro's Afterword is really an extended disquisition on the nature and power of love or more specifically, on the power of love over other earthly powers. 
Sugat na hindi na magagamot ang pagpapairal ng kapangyarihan ng isang may mataas na tungkulin sa isang mababa, parang sa pag-ibig, ang lakas o kapangyarihan ay hindi magagapi; datapwa kapag ang tunay na pagibig ang namayani, ay walang hadlang at walang kapangyarihang kikilalanin at ang maguutos na kanyang pangatawanan ang pagirog ay ang kapangyarihan ng puso. $(149)^{15}$

In some ways, the logic of Lazaro's essay sounds vaguely like Roke's afterword to his own version of this story. Both highlight the redemptive powers of love and identify this fact as crucial to the story of Romeo and Juliet. Among the earlier Filipino translators, this was perhaps understood as the story's essence and its final authority. The point of translation was hardly Shakespeare but only Love.

In the face of love worth dying for everything else ceases to matter. The enshrining of the love story of Romeo and Juliet in the vernacular canons shows just how the Filipino predilection for a good love story trumps official colonial history. Reading audiences in the vernacular were in all likelihood wrenched by the tragic fate of true love in Romeo and Juliet and consoled by its promise of a better future against all odds. With stunning disregard for the "official" Shakespeare of the schools, of the colonial icon Shakespeare, vernacular writers have in effect installed a Shakespearean icon of their own. In a way, the popularity of Romeo and Juliet and its multiple translations is symbolic of the transcendence of true love over the world of colonial politics. In effect, these early translators "reformulate(d) the foreign into an element of oneself" and "invest(ed) it with the power to underwrite the coming of the future." This practice of translation is one that Vicente Rafael also calls nationalism (xvii; 19-20).

It may be odd to liken the translation of foreign texts to the practice of nationalism but Lazaro's Afterword already hints at the possibility. Jose Rizal's texts, Lazaro argues, were also translated. More curiously, Lazaro finds another similarity between Rizal and Shakespeare. Through translations of Rizal's novel, Noli Me Tangere, Lazaro claims that Rizal was able to expose the evils of those in power in the country at the time but in the process of the exposure of corruption, he also created a model for true love.

Ang Noli ni Rizal ay napahulog sa iba ibang wika, palibhasa'y nais na makalat ang mga kabulukang dinalirot niyang naghari dito sa Pilipinas, ang mga kataksilang pinaiiral ng panahong yaong hindi mapalantad, ang mga kasawaang ipinakikilala ng mga nakapangyayarihan, ang mga pangaapi sa kabuhayan ng mga mamamayan, subali't sa pagbubukas niya ng takip ng tapayan ng kabulukan, sumingaw man ang baho ng mga mapaghariharian, ay ikinalat naman ang bango ng isang matamang pag-iibigan.

Nailarawan ang isang Ibarra at isang Maria Clara.

Gaya ng pagpapakilala ng tunay na pagibig ng isang Hulyeta at ng isang Romeo. $(146-147)^{16}$ 
If Shakespeare gave us Romeo and Juliet, Rizal gave us Ibarra and Maria Clara. Much like in Verona, amidst the strife and corruption of our own land, lies the redemption of true love (tunay na pag-ibig). In the case of both Rizal's and Shakespeare's lovers, true love is marred by tragedy. Or perhaps love is rendered even more true because it was, from its inception, already doomed, tragic, thwarted, forlorn, unfortunate, ill-fated or in a word-sawi. The notion of sawi is the untranslatable at the heart of both Rizal's and Shakespeare's tales of love. It embodies and inhabits a cultural sublime that is unseen but felt and only ever partially and unsatisfactorily articulated. It is a powerful, albeit untranslatable, notion contained in a word that is exclusively used in relation to love (sawi sa pagibig), violent or catastrophic death (nasawi), and country (ang bayan kong sawi). Love, death, and country come together in Rizal's Noli as they do in Shakespeare's play. Ironically, it is the untranslatable sawi shared by and powerfully embodied in both Rizal and Shakespeare that makes Romeo and Juliet a ceaselessly and in Derrida's sense a triumphantly translated text in Philippine literatures.

If as Benjamin proposes "the task of the translator [is] to release in his own language that pure language which is under the spell of another, to liberate the language imprisoned in a work in his re-creation of that work" (22), it would seem that the early Filipino translators understood pure language to be pure love. Hence, in local translations of the Shakespearean text a strict adherence to form or a fidelity to narrative details mattered far less than the capturing, or more accurately, releasing hints of a cultural sublime contained in the Shakespearean text and rendering it intelligible in a local language and form. They occupy a space of inbetweenness that is and is not Shakespeare at the same time. An active maker of the afterlife of Shakespeare's text, Filipino translations of Shakespeare, especially of Romeo and Juliet, reside in that undiscovered country where "the harmony of the languages is so profound that sense is touched by language only the way an aeolian harp is touched by the wind" (Benjamin 23). 


\section{Notes}

Research for this project was conducted through a Creative Work and Research Grant from the University of the Philippines. Mr. Leif Andrew Garinto and Mr. Nathaniel Marte provided research assistance and translations for Bikolano and Hiligaynon texts. Mr. Garinto also provided all textual translations into English.

1. Of course, Craig's vested political interests are at play here. The only other easily recognizable volume in the photograph is a large version of Webster's English Dictionary allying Rizal further with the English language and culture that the American colonials imposed on the Philippines in the early twentieth century. The biography itself, subtitled A Study of the Growth of Free Ideas in the Trans Pacific American Territory speaks volumes of its motivations.

2. Marvin Carlson describes the text of Rossi's Hamlet as "based on the prose translation of Rusconi, but corrected by Rossi's own study of the play and by comparison with the Kean promptbook. This gave a better approximation of the play (at least in overall structure) than the Salvini version, though it was not much improvement line by line for those who understood Italian. The Italian-English libretti sold at the theaters only emphasized the problem, since the anonymous English translator seemingly could not decide whether to follow literally the rather flat Italian or to slip into the familiar Shakespearean lines" (137-138).

3. The "classroom confinement" and other pedagogical deployments of Shakespeare within the history of the American colonial education system in the Philippines is further discussed in Ick, "Local Shakespeares, Shakespearean Locales" and "Illonggos, Igorottes, Merchants and Jews." An instructive comparison to the British colonial educational practices in Malaya and Singapore, where colonial institutions supported the translation and publication of Shakespeare in local languages, is offered in "Performing Shakespeare in Colonial Southeast Asia." For a wider comparative perspective that includes colonial Dutch Indonesia, see "Shakespeare, (Southeast) Asia, and the Question of Origins.

4. "Not my own work but derived from a source, adjusted accordingly with appropriate symbols included." All translations into English were provided by $\mathrm{Mr}$. Leif Andrew Garinto.

5. "O parents who think ill of their child

To be with someone they love not

Why force them, for they will only suffer When forced, their true destinies unfulfilled"

6. A manuscript of this sarswela is housed at the West Visayas Studies Center at the University of the Philippines in Iloilo. My gratitude to the staff of the WVSC and the UPV Iloilo Library for providing access to this important document. Translation and information about the text was provided by Mr. Alfredo Nathaniel Marte. Further details of the Magno's life and career are found in Rosario Cruz Lucero's unpublished MA thesis, "The zarzuelas of Salvador C. 
Magno: conventions, imitation, and originality" (University of the Philippines, 1980).

7. "Young women these days are different. They know karate and judo. Those young men who think of playing them for fools, I know not where your heads will be buried when caught.

So my advice to all young men, choose your beloved wisely. Being with someone you truly love, regardless of their looks, is like being served with a satisfying dessert after a hearty meal."

8. The slight exception would be De Leon's Bulag na Pagibig that makes a parenthetical reference to Shakespeare as textual source on the inside title page but does not include Shakespeare's name in the novel's title.

9. I would like to acknowledge the anonymous reviewer of an earlier draft of this essay who offered valuable insights into the nature of postcolonial translation and led me to further refine my initial thoughts. The concept of translation as a process of making the foreign into one's own is, of course, derived from Vicente Rafael to whom this essay owes a great intellectual debt.

10. "Verona, isa n gayon sa mañga magagandang Ciudad nang Cahariang Italla, sa dacong Amihanan. Ipinundar nang mañga taga Galia ó Etruria. Pagana nang Emperador Tito nang 82, taon nang cumapal, ang balitang anfiteatro sa Verona, na pinagtatagan nang piesta ó iba pang catouaan nang bayan. Ang Verona'y naguing sabana nang maraming digma. Nang taong 312 tinalo ni Constantino; at nahulog din sa capangyarihan ni Teoderico el Grande nang masupil niya si Odoacer na Hari sa Italla nang ica 27 nang Septiembre nang 489. Nang 774 sinalacay nang caunaunahang Hari sa Franciang si Carlomagno. Nang 1260 nahalal na Podesta ó Taga pamahalang Ciudad si Mastino della Scala, at nañgaghalinhinan ang caniyang mañga ancan na cung tauaguin Scaligeri hangang sa 1387 na sila'y talunin sa digma nang Viscondeduque sa Milan (isa sa mañga ancang Scaligeri ang Principeng Taga pamahalang Ciudad sa Verona sa panahong tinahac niyaring auit). Nang 1405 quinongquista nang Venecia at pinamahalaang maicling panahon ó hangang sa ica 3 nang Junio nang 1796 na sila'y talunin nang General frances Massena. Malapit sa Verona napipilan cay Cárlos Alberto de Cerdeña ang mañga taga Austria nang ica 6 nang Mayo nang 1848. Ang Verona ay naguing isa sa apat na matitibay na moog nang Austria at pinañgalanang cuadrangulo, pagcat nacapasico ang bauat panig nang pagcatabas salop nang cuta, at gayo'y siyang catibayan sa digma; at dito rin nang ica 12 nang Julio nang 1859 sa isang Orden del dia, ipinahayag nang Emperador Francisco José nang Austria ang boo niyang pag-ayos sa layon nang caramihan nang bayan na nanghihimagsic laban sa hindi macasundong caniyang pamamahala; at sa cayo'y calaquip ang pasasalamat sa munting bahagui nang bayan at hocbong caniyang caayon. Ang Verona'y nasanib sa cahariang Italla na ninanasang sumacop sa caniya mula nang ica 16 nang Octubre nang 1866, at nang ica 18 nang Noviembre nang taon ding ito, ang Hari sa Italla tinangap na ipinagidiuang nang may 7o,ooo catauo sa naturang anfiteatro. Nang taong 1877 natuclasan sa malapit sa Verona ang humuguit sa 50,ooo salaping may larauan ni Galeno't iba pang mañga emperadores at ang caramiha'y tangso. Nang 1881 ang cabilan gan nang namamayan sa Verona ay 60,768." 
(Verona, one of the most beautiful cities in the kingdom of Italy, is located on the island's northeast. Established by the Galians or the Etrurians, control was consolidated by the Emperor Titus in $82 \mathrm{AD}$, the same year when the amphitheater in Verona, scene of festivities and public holidays, was built. Verona was also the scene of many wars. In $312 \mathrm{AD}$, it was conquered by the emperor Constantine, and the city also fell to the control of Theodoric the Great when he defeated the then King of Italy, Odoacer, on September 27, 489 AD. In 774 the city was besieged by the newly-crowned King of France, Charlemagne, and in 1260 Mastino della Scalla was elected Podesta, or administrator, of the city. He and his heirs, named the Scaligeri, continued to rule the city until 1387, when they were defeated in battle by the Dukes of Milan. (The city administrator in this particular work is a Scaligeri.) Venice conquered the city in 14.05 and ruled it until June 3, 1796, when the Venetians were defeated in battle by General Francis Massena. Charles Albert, then ruler of Sardinia, was defeated by the Austrian army near the walls of Verona on May 6, 1848. Verona thus came under Austrian rule and became one of the four Austrian strongholds during the first War of Italian Independence. The city was nicknamed the 'quadrangle', for the city had four entry and exit points and was heavily guarded. On July 12, 1859, then Austrian emperor Franz Joseph acceded to the demands of the Veronese who were rebelling against Austrian rule, by way of thanking the Veronese for their assistance to the Austrian army during the war. Verona once again became part of the Kingdom of Italy on October 16, 1866, and on November 18th of the same year, 70,0oo people welcomed the King when he made an appearance in the Verona amphitheater. In the year 1877, almost 50,00o bronze coins bearing the image of Galen and other Roman emperors were discovered near Verona. The city's population was 60,768 in 1881 .)

11. "Unwanted and unfortunate circumstances led

To the disintegration of the city

By the southwest of the island

Strangers now occupy the town."

12. "You may have been seen only as a luminous lady

Whose beauty has been fought over

By generations of men from different clans

Yet true love from you has also sprung forth."

13. Whatever the political implications of these textual hints might be are definitely "silenced" by the 1914 edition of this text that no longer includes the foreword or afterword. And the author is further obscured by the change in pseudonym from G.D. Roke to Gedeere. Aside from some updating in language and spelling and a slight abridging of the text, there are no more obvious changes to the 1914 edition except the eradication of the author's textual traces. I wonder why that is.

14. "The mind of man transcends all. Proper virtues are passed on not only to their fellow countrymen, but for the whole world to benefit from it, as well. There are events that will be remembered without end, and there are works that will truly stand the test of time... 
"Shakespeare, the celebrated author... should not only be read by a select few, but by everyone."

15. "Trampling on the rights of the oppressed by those in power leaves wounds that will never heal. However, no matter the adversity, love will always prevail. If true love is allowed to prevail, it will overcome misfortunes and will recognize no other power. The power of true love will compel lovers to stay true to their bond regardless of difficulties sent their way."

16. "Rizal's Noli has been translated into different languages in order to expose the evils of those who conquered the Philippines, the rampant corruption that was hidden from public view, the unspeakable acts of those in power, the tyranny towards the oppressed. However, by opening the lid and exposing the stench from the cauldron of filth kept by those in power, Rizal has also spread the sweet smell of pure love through the relationship between Ibarra and Maria Clara.

"The love between Ibarra and Maria Clara is comparable to the true love shared by Juliet and Romeo."

\section{Works Cited}

Aguas, Juan. "Juan Crisostomo Soto and Pampangan Drama." The Diliman Review 10.3 (1962). Print.

Antonio, Lilia. Apat na Siglo ng Pagsasalin: bibliograpiya ng mga pagsasalin sa Filipinas, 1593-1993. Quezon City: Sentro ng Wikang Filipino, 1999. Print.

Benjamin, Walter. "The Task of the Translator." The Translation Studies Reader. Ed. Lawrence Venuti. London: Routledge, 2000. 15-25. Print.

Bernad S.J., Miguel. Dramatics at the Ateneo de Manila: A History of Three Decades, 19211952. Manila: Ateneo Alumni Association, 1977. Print.

BINATOR and Dulaang Sipat Lawin. R'meo Luvs Dew-lhiett (A jologs adaptation of Shakespeare's love classic). N.d. TS. Tanghalang Pilipino, Cultural Center of the Philippines, Manila.

Borlaza, Gregorio. Romeo at Julieta ni William Shakespeare. Manila: Philippine Women's University/Bayanihan Folk Arts Center, 1968. Print.

Carlson, Marvin. The Italian Shakespeareans: Performances by Ristori, Salvini, and Rossi in England and America. New Jersey: Associated UP, 1985. Print.

Craig, Austin. The Life, Lineage, and Labors of Jose Rizal, Philippine Patriot: A Study of the Growth of Free Ideas in the Trans-Pacific American Territory. Manila: Philippine Education Co., 1913. Print.

Cruz, Isagani, ed. A Short History of Theater in the Philippines. Manila: Cultural Center of the Philippines, 1971. Print.

Cuasay, Pablo. Sa Kagustuhan Mo. Navotas: National Bookstore, 1975. Print.

De Jesus, Jose Corazon. "Julieta at Romeo." Bulag ang Pag-ibig. By Pascual de Leon. Manila: Libreria de P. Sayo vda. De Soriano, 1918. 151-154. Print.

De Leon, Pascual. Bulag ang Pag-ibig. Manila: Libreria de P. Sayo Vda. De Soriano,1918. Print. 
De Man, Paul. “'Conclusions' on Walter Benjamin's 'The Task of the Translator.'” The Resistance to Theory. Minneapolis: U of Minnesota P, 1986. 73-105.

Derrida, Jacques. "Living On." Deconstruction and Criticism. 3rd ed. Ed. Harold Bloom. New York: Continuum, 2004. 62-142. Print.

De Unamuno, Miguel. "Rizal: The Tagalog Hamlet." Rizal: Contrary Essays. Ed. Petronilo Daroy and Dolores Feria. Quezon City: Guro, 1968. 3-16. Print.

Eugenio, Damiana L. Awit and Corrido: Philippine Metrical Romances. Quezon City: U of the Philippines P, 1987. Print.

Fitzgerald, Thomas. "Shakespeare in Spain and Spanish America." Modern Language Journal 35.8 (1951): 589-594. Print.

Gedeere. Julieta at Romeo (Sintahang Dalisay). Manila: Libreria J. Martinez, 1914. Print.

Ick, Judy Celine. "Shakespeare, (Southeast) Asia, and the Question of Origins."

Shakespeare in Culture. Ed. Bi-qi Beatrice Lei and Ching-His Perng. Taipei: National Taiwan UP, 2012. 205-229. Print.

--.. "Performing Shakespeare in Colonial Southeast Asia." The Asian Scholar 4 (n.d.): n. pag. Web. 5 May 2013.

--.. "Ilonggos, Igorottes, Merchants, and Jews: Shakespeare and American Colonial Education." Humanities Diliman 1.1 (2000): 109-134. Print.

--..'Local Shakespeares, Shakespearean Locales." Public Policy 3.1 (1999): 64-81. Print.

Imperial Sr., Rosalio. Maogma asin mamundong AgiAgui Ken Inaguihan na Buhay ni Romeo asin Juliet sa Ciudad Nin Verona. Naga City: Cecilio, n.d. Print.

Jamias, Cristino. The University of the Philippines: The First Half Century. Quezon City: Diliman Review UP Golden Jubilee Special Supplement, 1962. Print.

Jurilla, Patricia May. Bibliography of Filipino Novels, 1901-200o. Quezon City: U of the Philippines P, 2010. Print.

Lorino, Zacarias. Si Romeo asin Julieta: gotos na kasaysayan sa rawitdawit. Legaspi: n.p., 1969. Print.

Magno, Salvador. Romeo kag Julieta: zarzuela. 1932. MS. West Visayas Studies Center, U of the Philippines, Iloilo City. Print.

Manuel, E. Arsenio. Dictionary of Philippine Biography. Vol. 1. Quezon City: Filipiniana, 1955.

Mojares, Resil. Theater in Society, Society in Theater: Social History of a Cebuano Village, 1840-1940. Quezon City: Ateneo de Manila UP, 1985. Print.

Philippine Islands, Bureau of Education. Courses of Instruction for the Public Schools of the Philippine Islands. Manila: Bureau of Public Printing, 1904. Print.

Racelis, Mary and Judy Ick. Bearers of Benevolence: The Thomasites and Public Education in the Philippines. Pasig City: Anvil, 2001. Print.

Rafael, Vicente. The Promise of the Foreign: Nationalism and the Technics of Translation in the Spanish Philippines. Pasig City: Anvil, 2006. Print.

Realubit. Ma. Lilia. Bikols of the Philippines. Naga City: AMS, 1983. Print.

Rizal, Jose. Diarios y Memorias. Manila: Republic of the Philippines Bureau of Print, 1961. Print.

-... Noli Me Tangere: A Novel. Trans. Soledad Lacson Locsin. Manila: Bookmark, 1996. Print.

Roke, G.D. Ang Sintang Dalisay ni Julieta at Romeo. Manila: Imprenta Tagala, 1901.Print. 
"Shakespeare-In-Pilipino." The University (1967): 22-30. Print.

Shakespeare, William. Ang Trahedya ni Hamlet Prinsipe ng Dinamarka. Trans. Rolando Tinio. Quezon City: U of the Philippines P, 1991. Print.

--. Ikalabingdalawang Gabi. Trans. Rolando Tinio. Pasig City: Anvil, 2012. Print.

--. Julio Cesar. Trans. Bienvenido Lumbera. Quezon City: Ateneo De Manila UP, 2007. Print.

--. Makbet. Trans. Rolando Tinio. Pasig City: Anvil, 2012. Print.

--. Romeo and Juliet. Ed. Asuncion David-Maramba. Mandaluyong: Cacho Hermanos, 1974. Print. 